\title{
AKAD AS-SULHU SEBAGAI INDUK PENYELESAIAN SENGKETA DALAM MU'AMALAH MENURUT IMAM JALALUDIN AS-SUYUTI
}

\author{
Ahmad Muflikhudin \\ ahmadkansya@gmail.com \\ IAIN Purwokerto
}

\begin{abstract}
This article aims to describe the As-Sulhu Akad as the root of dispute resolution in mu'amalah. The research method in this article was carried out by studying the literature on the works of classical scholars. The results of this study explain that dispute cases are resolved through courts (litigas), and some are resolved amicably (out of court) or non-litigation. In Islamic economic law, solving problems outside the court is termed as tahkim and As-sulhu. According to Imam Jalaludin As-Suyuti in the Asbah Wanadhoir book, it is explained that AS-Sulhu (negotiation) can include buying and selling, leasing, and accounts payable. The positive impact expected from this article is that Muslims can use the As-Sulhu Akad as a strategic step in solving problems.
\end{abstract}

\section{Keywords: Muamalah, As-Sulhu, Imam Jalaludin As-Suyuti}

\begin{abstract}
Abstrak
Artikel ini bertujuan untuk mendeskripsikan Akad As-Sulhu Sebagai akar penyelesaian sengketa dalam mu'amalah. Metode penelitian dalam artikel ini dilakukan dengan studi pustaka pada karya-karya ulama klasik. Hasil dari penelitian ini dijelaskan bahwa penyelesain kasus persengketaan dilakukan melalui pengadilan (litigas), dan juga ada yang diselesaikan secara damai (diluar pengadilan) atau non litigasi. Pada hukum ekonomi islam, menyelesaikan permasalahan diluar pengadilan di istilahkan dengan tahkim dan As-Sulhu. Menurut imam Jalaludin As-Suyuti dalam kitab asbah wanadhoir dijelaskan bahwa AS-Sulhu (negosiasi) bisa mencakup jual beli, sewa menyewa, dan hutang piutang. Selanjutnya didalam kitab tausyeh 'ala ibnu qosim di jelaskan bahwa As-Sulhu merupakan induk dari pada beberapa hukum hususnya hukum muamalah artinya bisa mengandung akad-akad muamalah yang lainya. Dampak positif yang diharapakan dari artikel ini secara luas umat Islam dapat menggunakan Akad As-Sulhu sebagai langkah setrategis dalam menyelesaikan masalah.
\end{abstract}




\section{Kata Kunci : Muamalah, As-Sulhu, Imam Jalaludin As-Suyuti.}

\section{A. Pendahuluan}

Dalam penjelasan terhadap pasal 49 UU nomor 3 tahun 2006 tersebut ditegaskan bahwa, Penyelesaian sengketa tidak hanya di bidang perbankan syaria'ah, melainkan juga di bidang ekonomi syaria'ah lainnya. Yang dimaksud dengan "antara orang-orang yang beragama Islam” adalah termasuk orang atau badan hukum yang dengan sendirinya menundukkan diri dengan sukarela kepada hukum Islam mengenai hal-hal yang menjadi kewenangan peradilan agama sesuai dengan ketentuan pasal ini.Setiap orang atau badan hukum yang melakukan transaksi dengan menggunakan akad syariah, berarti dia menundukkan diri secara sukarela. Dengan sebutan perbuatan atau kegiatan usaha, maka yang menjadi kewenangan pengadilan agama adalah transaksi yang menggunakan akad syari’ah, walaupun pelakunya bukanmuslim. Ukuran Personalitas keIslaman dalam sengketa ekonomi syari'ah adalah akad yang mendasari sebuah transaksi, apabila menggunakan akad syari’ah, maka menjadi kewenangan peradilan agama.

Dalam konteks ini pelaku non muslim yang menggunakan akad syari'ah berarti menundukkan diri kepada hukum Islam, sehingga oleh karenanya UU Nomor 3 Tahun 2006 menentukan bahwa sengketanya harus diselesaikan di pangadilan agama. Sejalan dengan itu maka yang disebutkan pada penjelasan pasal demi pasal UU No.3/2006 pasal 49 huruf I, Yang dimaksud dengan ekonomi syari'ah, adalah perbuatan atau kegiatan usaha yang dilaksanakan menurut prinsip syari'ah, harus dimaknai bahwa kewenangan Pengadilan Agama menjangkau kalangan non muslim yang bertransaksi (menggunakan akad) syari'ah. Tindakan non muslim yang melibatkan dirinya dalam kegiatan ekonomi syari'ah dipandang sebuah penundukan diri secara terbatas terhadap hukum Islam.

Didalam penyelesain masalah persengketaan didadalam masalah ekonomi ada yang di selesaiakan dengan cara ligitasi dan non ligitasi. Adapun ligitasi yang menyelesaikan persengketaan adalah pengadilan agama dan 
pengadilan negeri.Sedangkan non ligitasi menyelesaikan masalah sengketa di luar pengadilan baik pengadilan negeri maupun pengadilan agama.Hal ini menyangkup mediasi, negosiasi, arbitrase, katalisasi.Mediasi adalah upaya penyelesaian sengketa dengan melibatkan pihak ketiga yang netral, yang tidak memiliki kewenangan mengambil keputusan, yang membantu pihak-pihak yang bersengketa mencapai penyelesaian (solusi) yang diterima oleh kedua belah pihak. ${ }^{2}$

Negosiasi adalah pengelolaan atau kesepakatan antara dua pihak dimana para pihak yang bersengketa berusaha untuk membujuk antara satu sama lain, menemukan titik dasar untuk diskusi, dan menjiwai jalan mereka melalui proses give-and-take ke arah mencari penyelesaian. ${ }^{3}$ Arbitrase adalah penyelesaian sengketa di luar peradilan, berdasarkan pada perjanjian arbitrase yang dibuat oleh para pihak, dan dilakukan oleh arbiter yang dipilih dan diberi kewenangan mengambil keputusan.Arbitrase merupakan pilihan yang paling menarik, khususnya bagi kalangan pengusaha.Bahkan, arbitrase dinilai sebagai suatu "pengadilan pengusaha" yang independen guna menyelesaikan sengketa yang sesuai dengan keinginan dan kebutuhan mereka.

Konsiliasi pada dasarnya hampir sama dengan mediasi, mengingat terdapat keterlibatan pihak ke-3 yang netral (yang tidak memihak) yang diharapkan dapat membantu para pihak dalam upaya penyelesaian sengketa mereka, yaitu konsiliator. Namun demikian, Anda perlu perhatikan bahwa konsiliator pada umumnya memiliki kewenangan yang lebih besar daripada mediator, mengingat ia dapat mendorong atau “memaksa” para pihak untuk lebih kooperatif dalam penyelesaian sengketa mereka.

\footnotetext{
${ }^{2}$ Khotibul Umam, Penyelesaian Sengketa diluar Pengadilan, (Yogyakarta: Penerbit Pustaka Yustisia, 2010), hlm. 10

${ }^{3}$ Steven Vago, Law and Society, New Jersey : Printice-Hall, 1988, hlm. 239
} 


\section{B. Pengertian al-shulhu, rukun, dan syarat}

Secara bahasa, kata al- shulhu ( قطع التراع مerarti ( الصلح artinya: Memutus pertengkaran atau perselisihan.Secara istilah(Syara') ulama mendefinisikan as-shulhu sebagai berikut:Menurut Taqiy al- Din Abu Bakar Ibnu Muhammad al- Husaini

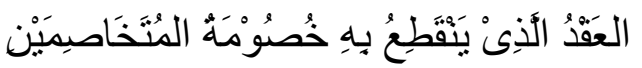

Artinya: "Akad yang memutuskan perselisihan dua pihak yang bertengkar (berselisih), ${ }^{4}$ sedangakan Hasby Ash- Siddiqie dalam bukunya Pengantar Fiqih Muamalah berpendapat bahwa yang dimaksud al- Shulhadalah:

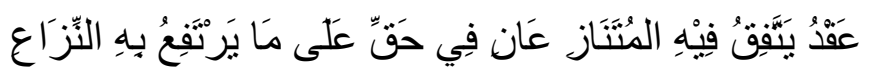

Artinya:Akad yang disepakati dua orang yang bertengkar dalam hak untuk melaksanakan sesuatu, dengan akad itu dapat hilang perselisihan. ${ }^{5}$

Selanjutnya Sayyid Sabiq berpendapat bahwa yang dimaksud dengan al-Shulhu adalah suatu jenis akad untuk mengakhiri perlawanan antara dua orang yang berlawanan. ${ }^{6}$ Dari beberapa definisi di atas maka dapat di simpulkan bahwa As-Shulhuadalah suatu usaha untuk mendamaikan dua pihak yang berselisihan, bertengkar, saling dendam, dan bermusuhan dalam mempertahankan hak, dengan usaha tersebut dapat di harapkan akan berakhir perselisihan. Dengan kata lain, sebagai mana yang di ungkapkan oleh Wahbah Zulhaily As-shulhu adalah akad untuk mengakhiri semua bentuk pertengkaran atau perselisihan. ${ }^{7}$ Dasar Hukum As- Shulhu yangdisyari'atkan oleh Allah SWT. Sebagaimana yang tertuang dalam Al- Qur'an:

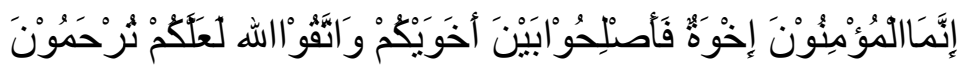

Artinya:"Sesungguhnya orang mukmin itu bersaudara, karena itu damaikanlah antara kedua saudaramu dan bertaqwalah kepada Allah supaya kamu mendapat rahmat”.

${ }^{4}$ Imam Taqiyuddin Abu Bakar Kifayah al- Akhyar, ( Bandung PT al- Marif, tt), hlm. 271

${ }^{5}$ Hasbi Ash Siddiqi, Pengantar Fiqih Muamalat,(Bulan Bintang: Jakarta, 1984), hlm.92

${ }^{6}$ Sayid Sabiq, Fiqh al- Sunnah,(Dar al- Fiqir, 1987), hlm.189.

${ }^{7}$ Wahbah Zuhaily, Al- Fiqih (Beirut: Dar Al- Fikr Al- Muashir, 2005), Jilid Iv, Hlm. 4330 
Dan juga di dalam surat (Qs. Al Hujurat : 10).

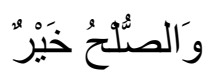

“Perdamaian itu lebih baik "(Al- Nisa:128)

Disamping firman- firman Allah, Rasulullah SAW. Juga menganjurkan untuk melaksanakan perdamaian dalam salah satu hadis yang di riwayatkan oleh Ibnu Hibban dan Tirmizi dari Umar Bin Auf Al- Muzanni Rasulullah Saw. Bersabda:

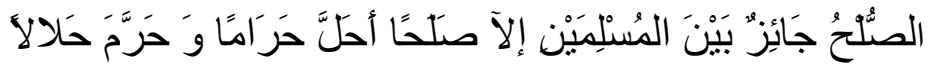

Artinya: Mendamaikan dua muslim (yang berselisih) itu hukumnya boleh kecuali perdamaina yang mengarah kepada upaya mengharamkan yang halal dan menghalalkan yang haram”. (HR. Ibnu Hibban dan Turmudzi).

Adapun Contoh menghalalkan yang haram seperti berdamai untuk menghalalkan riba. Contoh mengharamkan yang halal berdamai untuk mengharamkan jual beli yang sah. Didalam al-sulhu ada Rukun dan Syarat as- Shulhu. Rukun as-Shulhu yaitu Musalih yaitu dua belah pihak yang melakukan akad sulhu untuk mengakhiri pertengkaran atau perselisihan.Mushalih 'anhu yaitu persoalanyang diperselisihkan.Mushalih bih yaitu sesuatu yang dilakukan oleh salah satu pihak terhadap lawannya untuk memutuskan perselisihan. Hal ini disebut dengan istilah badal al-Shulhu ${ }^{8}$. Shigat ijab kabul yang masing-masing dilakukan oleh dua pihak yang berdamai. Seperti ucapan “aku bayar utangku kepadamu yang berjumlah lima puluh ribu dengan seratus ribu (ucapan pihak pertama)”. Kemudian, pihak kedua menjawab “saya terima”. Jika telah di ikrarkan maka

${ }^{8}$ Fadilah Qotimatun Puji Rahayu, “Analisis Akta Perdamaian Sengketa Ekonomi Syariah Di Pengadilan Agama Sragen Di Tinjau Dari Al - Shulhu Dan Perma No. 1 Tahun 2016 Tentang Prosedur Mediasi Di Pengadilan,” Jurnal Al-Hakim: Jurnal Ilmiah Mahasiswa, Studi Syariah, Hukum Dan Filantropi 2, No. 2 (28 September 2020): 34; Havis Aravik, "Penyelesaian Sengketa Konsumen Melalui Jalur Al-Shulhuh Dan Jawatan Al-Hisbah,” Ekonomica Sharia 1, No. 2 (27 Februari 2016): 36; Mohd Zafar Ashraf Bin Zulkarnain, "Proses Penyelesaian Sengketa Suami Istri Padalembaga Shulh Mahkamah Rendah Syariahkuala Krai, Kelantan Darul Naim,Malaysiamenurut Perspektif Hukum Islam” (Skripsi, Universitas Islam Negeri Sultan Syarif Kasim Riau, 2015), 76, Http://Repository.Uin-Suska.Ac.Id/7325/. 
konsekuensinya kedua belah pihak harus melaksanakannya. Masing - masing pihak tidak dibenarkan untuk mengundurkan diri dengan jalan memaksanya kecuali di sepakati oleh kedua belah pihak ${ }^{9}$.

Adapaun Syarat-syarat As-sulhu: ada Syarat yang berhubungan dengan Musahlih (orang yang berdamai) yaitu disyaratkan mereka adalah orang yang tindakannya di nyatakan sah secara hukum. Jika tidak seperti anak kecil dan orang gila maka tidak sah Syarat yang berhubungan dengan Musahlih bih yaitu; Berbentuk harta yang dapat di nilai, diserah- terimakan, dan berguna.Di ketahui secara jelas sehingga tidak ada kesamaran yang dapat menimbulkan perselisihan.Syarat yang berhubungan dengan Mushalih 'anhu yaitu sesuatu yang di perkirakan termasuk hak manusia yang boleh diiwadkan (diganti).Jika berkaitan dengan hak- hak Allah maka tidak dapat bershulhu.Secara garis besar as-sulhu terbagi menjadi dua yaitu; as-sulhu al-hathitah yaitu akad as-sulhu dengan cara mengambil sebagian barang yang di persengketakan, dan al-sulhu al-mu'awadhah yaitu akad al-sulhu dengan cara mengganti barang yang di persengketakan, al-sulhu ini hukumnya seperti jual beli.

Macam-macam As-hulhu Dijelaskan dalam buku Fiqih, Syafi'iyah oleh Idris Ahmad bahwa al- shulhu (perdamaian) di bagi menjadi 4 bagian berikut ini. Pertama, Perdamaian antara muslimin dengan kafir, yaitu membuat perjanjian untuk meletakkan senjata dalam masa tertentu, secara bebas atau dengan jalan mengganti kerugian yang di atur dalam undang - undang yang di sepakati dua belah pihak. Kedua, Perdamaian antara kepala negara (Imam/ Khalifah) dengan pemberontak, yakni membuat perjanjian- perjanjian atau peraturan mengenai keamanan dalam negara yang harus dia taati, lengkapnya dapat di lihat dalam pembahasan khusus tentang bughat. Ketiga, Perdamaian

${ }^{9}$ Esti Yuwanita, “Hubungan Antara Kualitas Perkawinan Orang Tua Dan Parenting Practices Dengan Regulasi Emosi Pada Remaja Sma Wahid Hasyim 1 Surabaya” (Undergraduate, Universitas Muhammadiyah Surabaya, 2017), 67, Http://Repository.Um-Surabaya.Ac.Id/2412/; Yayat Dimyati, Hasyim Asy’ari, Dan Musoto Mustoto, "Efektifitas Mediator Dalam Menekan Tingkat Perceraian,” Jurnal Mahkamah $\square$ : Kajian Ilmu Hukum Dan Hukum Islam 4, No. 1 (16 Juli 2019): 170, Https://Doi.Org/10.25217/Jm.V4i1.398; Fadilla Fadilla, "Permasalahan Ekonomi Sesungguhnya Dalam Islam,” Islamic Banking $\square$ : Jurnal Pemikiran Dan Pengembangan Perbankan Syariah 3, No. 1 (31 Agustus 2017): 67. 
antara suami dan istri yaitu membuat perjanjian dan aturan - aturan pembagian nafkah, masalah durhaka, serta dalam masalah haknya kepada suaminya manakala terjadi perselisihan. Keempat, Perdamaian dalam mua’malah, yaitu membentuk perdamain dalam masalah yang ada kaitannya dalam perselisihan yang terjadi dalam masalah muamalat. ${ }^{10}$

Didalam kitab fiqih manhaji dijelaskan bahwa ada 5 jenis rekonsiliasi/as-sulhu yaitu sebagai berikut:

1. Rekonsiliasi antar negara, yang di kenal dengan konsep hudnah (perjanjian genjatan senjata) berdasarka dengan firman Allah SWT sebagai berikut;

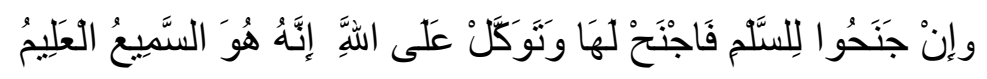

Artinya; Dan jika mereka condong kepada perdamaian, maka condonglah kepadanya dan bertawakkallah kepada Allah. Sesungguhnya Dialah Yang Maha Mendengar lagi Maha Mengetahui.(Al-qur'an Surat Al-Anfal Ayat 61)

2. Rekonsiliasi antara pemerintah dengan kelompok pembrontak, yang dikenal dengan konsep bughah (makar), berdasarkan firman Allah SWT sebagai berikut;

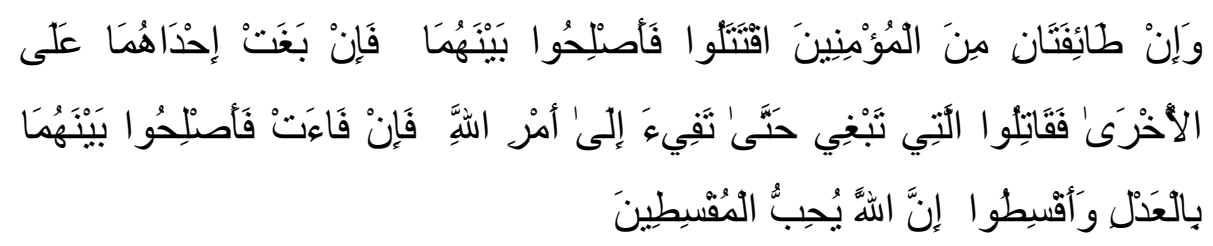

Artinya; Dan kalau ada dua golongan dari mereka yang beriman itu berperang hendaklah kamu damaikan antara keduanya! Tapi kalau yang satu melanggar perjanjian terhadap yang lain, hendaklah yang melanggar perjanjian itu kamu perangi sampai surut kembali pada perintah Allah. Kalau dia telah surut, damaikanlah antara keduanya menurut keadilan, dan hendaklah kamu berlaku adil; sesungguhnya Allah mencintai orang-orang yang berlaku adil.

${ }^{10}$ Muhibin Aman Aly, Mengenal Istilah Dan Rumus Fuqaha: Kediri, Madrasah Hidayatul Mubtadiin, 2002, hlm. 65 
3. Rekonsiliasi antara suami istri ketiaka terjadi konflik rumah tangga, yang dikenal dengan konsep syiqaq, nusyuz, dan qasam, berdasarkan firman Allah SWT sebagai berikut :

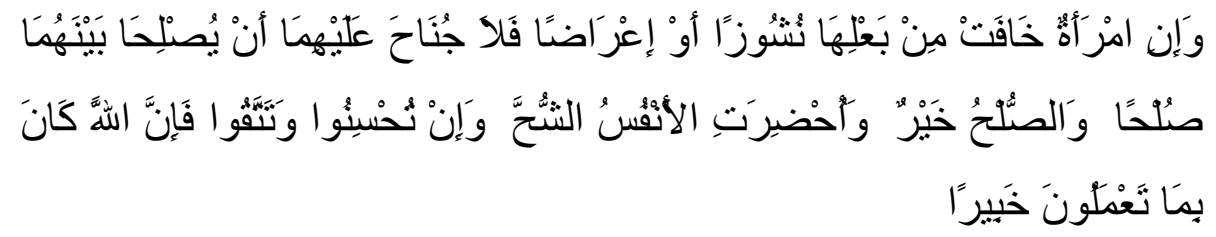

Artinya; Dan jika seorang wanita khawatir akan nusyuz atau sikap tidak acuh dari suaminya, maka tidak mengapa bagi keduanya mengadakan perdamaian yang sebenar-benarnya, dan perdamaian itu lebih baik (bagi mereka) walaupun manusia itu menurut tabiatnya kikir. Dan jika kamu bergaul dengan isterimu secara baik dan memelihara dirimu (dari nusyuz dan sikap tak acuh), maka sesungguhnya Allah adalah Maha Mengetahui apa yang kamu kerjakan. (al-qur'an surat An-Nisa Ayat 128.

4. Rekonsiliasi antar kelompok ketika terjadi konflik komunal yang bukan berkaitan dengan harta benda berdasarkan hadist;

$$
\begin{aligned}
& \text { فقد روي سـل بن سعد ان اهل قباء اقتنلو ا حتى تر امو ا بالحجارة فاخبر رسول } \\
& \text { الله بذلك فقال اذهبو ا بنا نصلح بينهم }
\end{aligned}
$$

Artinya; sahal bin sa'id meriwayatkan bahwa penduduk kuba' saling bertengkar sampai saling melempar batu kemudian rasulullah memberi intruksi, beliau berkata; pergilah kepada mereka dan damaikanlah diantara mereka.

5. Rekonsiliasi antar pihak (mudda'i dan mudda'a 'alaih) dalam muamalah yang melibatkan materi (maliyah).

\section{Biografi Imam Jalaluddin As-Suyuthi.}

Nama lengkapnya adalah Abdurrahman bin Abi Bakar bin Muhammad bin Saabiquddien bin al-Fakhr Utsman bin Nashiruddien Muhammad bin Saifuddin Khadhari bin Najmuddien Abi ash-Shalaah Ayub ibn Nashiruddien Muhammad bin asy-Syaich Hammamuddien al-Hamman 
al-Khadlari al-Asyuuthi Lahir setelah Maghrib, hari Ahad malam, bulan Rajab tahun 849 Hijriyah, yakni enam tahun sebelum bapaknya wafat.. ${ }^{11}$

Nama al-Khudhairi diambil dari nama desa al-Khudhairiyah dekat Baghdat. Hal ini diakui oleh Suyuthi sendiri meskipun semasa hidupnya terdapatdua nama al-Khudhairiyah masing-masing di as-suth dan Kairo. Barangkali penegasan Suyuthi ini untuk mengembalikan jejak nenek moyangnya dari sebuah wilayah yang jauh dan terkenal. ${ }^{12}$

\section{Pendidikan dan Guru-Gurunya.}

Jalaluddien as-Suyuthi berasal dari lingkungan cendekiawan sejak kecilnya.Bapaknya berusaha mengarahkannya ke arah kelurusan dan keshalihan.Adalah beliau hafal Alquran di usianya yang sangat dini dan selalu diikutkan bapaknya di berbagai majlis ilmu dan berbagai majlis qadhinya.

Bapaknya, yakni Kiai Abu Bakar, telah memintakan kepada Imam Ibnu Hajar al-‘Asqalani supaya mendo’akannya diberi berkah dan taufiq. Bapaknya melihat dalam diri anaknya seperti yang didapati dalam diri Ibnu Hajar, hingga ketika beliau minum, sebagian diberikan kepada anaknya dan mendo’akannya agar ia seperti Ibnu Hajar, menjadi ulama yang trampil dan tokoh penghafal (hadis).

Bapaknya wafat saat ia (Imam Suyuthi) baru berumur lima tahun tujuh bulan. Tetapi Allah telah memeliharanya dengan taufiq dari-Nya dan mengasuhnya dengan asuhan-Nya.Ini terbukti dengan telah ditakdirkan Allah Ta’ala untuknya al-‘Allamah Kamaaluddien bin Humam al-Hanafi pengarang Fathul Qadir untuk menjadi guru asuhnya.Hingga hafal Alqur'an dalam umur delapan tahun, kemudian menghafal kitab al-’Umdah lalu Minhajul Fiqhi dan Ushul, serta Alfiyah Ibnu Malik.Dan mulai menyibukkan diri dengan ilmu pada tahun $864 \mathrm{H}$, yakni ketika berumur 15 tahun.Menimba ilmu Fikih dari Syaikh Sirajuddin al-Balqini.Bahkan mulazamah kepada beliau hingga wafatnya.Kemudian

11 Jalaluddin Suyuthi, al-Asybah wa an-Nadzair, (al-Qahirah: Maktabus tsaqafi, 2007), h. 15

12 Yusrin Abdul Ghani Abdullah, Historiografi Islam Dari Klasik Hingga Modern, (Jakarta: 
mulazamah kepada anak beliau, dan menyimak banyak pelajaran darinya seperti al-Haawi ash-Shaghir, al-Minhaaj, syarah al-Minhaaj dan ar-Raudhah.Belajar Faraidl dari syaikh Sihaabuddien Asy-Syaarmasaahi, dan mulazamah kepada asy-Syari al-Manaawi Abaaz Kuriya Yahya bin Muhammad, kakak dari Abdurrauf pensyarah al-Jami’ ash-Shaghir.

Kemudian menimba ilmu bahasa Arab dan ilmu hadis kepada Taqiyuddien asy-Syamini al-Hanafi (872 H).Selanjutnya beliau mulazamah kepada syekh Muhyiddien Muhammad bin Sulaiman ar-Rumi al-Hanafi selama 14 tahun. Dari beliau ia menimba ilmu tafsir, ilmu ushul, ilmu bahasa Arab dan ilmu ma’ani. Juga berguru kepada Jalaaluddien al-Mahilli (864 H) dan 'Izzul Kinaani Ahmad bin Ibrahim al-Hanbali. Dan membaca Shahih Muslim, asy-Syifa, Alfiyah Ibnu Malik dan penjelasaannya pada Syamsu as-Sairaami.

\section{Karya-karya imam jalaludin as-suyuti}

Berikut ini pembahas kutipkan sebagian karya-karya Imam Suyuthi:

\section{a. Tafsir dan Ulumu al-Qur'an}
1) Tafsir al-Jalalain.
2) Lubabu an-Nuqul fi Asbab an-Nuzul.
3) Durr al-Mantsur fi at-Tafsir bi al-Maktsur
4) Al-Itqan fi Ulumi al-Qur'an
5) Iklil fi Istinbathi at-Tanzil
6) An-Nasikh wa al-Mansukh
7) Mafhamatu al-Akran fi Mubhamati al-Qur'an

\section{b. Ulumu al-Hadits}
1) Ad-Dibaj ‘Ala Tashhihi Muslim bin Hajaj
2) Al-Khashaishu al-Kubra
3) Al-Jami'u al-Shagir
4) Ad-Duraru al-Muntasyirah fi al-Ahaaditsu al-Musytahirati

PT Raja Grapindo Persada, 2004), cet. ke-1, h. 85 


\section{c. Fiqh}

1) Al-Washailu ila Makrifati al-Awaail

2) Al-Raddu 'ala man Akhlada ila al-Ardi wa Jahlu Anna Ijtihada fi Kulli ‘Ashrin fardhu.

3) Al-Asybah wa an-Nadzairu al-Fiqhiyah

\section{d. Ulumu al-Balaghah}

1) Qu'udul al-Jaman fi Ilmi al-Ma’ani wa al-Bayan

2) Syabihatu bi al-fiyati Ibnu Maliki fi an-Nahwi wa al-Sharpi

\section{e. Tarekh dan Adab}

1) Husnu al-Muhadharah Akhbaru Mishra wa al-Qahirah

2) Terekh al-Khulafa'

3) fi Ilmi at-Tarekh

4) Tuhfatu al-Kiram

5) Bughyatu al-Wi'at fi Thabaqat al-Lughawin wa an-Nuhat

6) Thabaqatu al-Huffadz

7) Thabaqatu al-Fuqaha al-Syafi'iyah

8) Tarekhu al-Suyuthi

\section{f. Tashawuf}

1) Tanbihu al-Ghabi

2) Al-‘Aridh

\section{g. Fiqh Lughah}
1) Al-Iqtirah
2) Muzhar fi Ulumi al-Lughah.. ${ }^{13}$

\section{h. Nahwu}
1) Jam’ul Jawami'
2) Hima’u al-Hawami' Syarhu Jam'u al-Jawami'
3) Kitab Asybah wa an-Nadzair an-Nahnwiyah. ${ }^{14}$

\section{Wafatnya Imamjalaludin as-suyuti}

13 Husyn Ahmad Amin mengungkapkan dalam bukunya: Buku Muzhar ini salah satu buku terpentingnya dalam bidang bahasa, karena dia mengungkap kembali pendapat-pendapat tokoh yang karangan-karangannya telah hilang. Husyn Ahmad Amin, Seratus Tokoh Dalam Sejarah Islam, (Bandung: PT Remaja Rosdakarya, 2006), cet. ke-9, h. 257 
Beliau menghembuskan nafas terakhirnya pada hari Jum'at bertepatandengan 17 Jumadil Ula atau 911 H (1505 M), setelah mengalami sakit selama seminggu akibat pembengkakan pada tangan kirinya.Dimakamkan di daerahHusy Qushun samping Bab Qurafa.

\section{Hubungan Akad As-Sulhu dengan Akad Akad Muamalah Yang Lain.}

Sayyid Sabiq bahwa al -shulhu (perdamaian) di bagi menjadi 3 macam. Yaitu: Perdamaian tentang iqrar, Perdamaian tentang inkar, Perdamaian tentang sukut; ${ }_{-}^{15}$ Adapun dilihat dari keabsahannya dibagi menjadi dua, Shulhu Ibra yaitu melepaskan sebagian dari apa yang menjadi haknya. Shulhu ibra ini tidak terkait oleh syarat. Shulhu Muawadah yaitu berpalingnya satu orang dari haknya kepada orang lain. Hukum yang berlaku pada sulhu ini adalah hukum jual beli. ${ }^{16}$ Dan akad-akad muamalah yang lainnya. Menurut syekh jalaludin as-susyuti didalam kitab asbah wanadhoir dan ulama yanag lain, disana dijelaskan bahwa subtansi as-sulhu adalah sebagia berikut;

1. Akad jual beli ba'i seperti, “aku berdamai dengan kamu atas rumah ini dengan ganti uang sekian”.

2. Akad sewa( ijarah). Seperti, “aku berdamai dengan kamu atas rumah ini dengan ganti manfaat motor ku selama satu tahun”.

3. Akad pinjaman. Seperti, mudd'a 'alaih mengatakan kepada mudd'i, “aku berdamai dengan kamu atas motor ini, yang akan aku kembalikan kepada mu setelah aku pinjam satu bulan”

4. Akad pesan. Seperti, “aku berdamai dengan kamu atas rumah ini, dengan ganti, kamu berikan pakaian dengan kriteria demikian”.17

5. Akad sayembara. Seperti, "aku berdamai dengan kamu atas rumah ini, dengan ganti kamu bisa menemukan barangku yang hilang”

14 Jalaluddin Suyuthi, op.cit., h. 17-18.

${ }^{15}$ Sayyid Sabiq, loc. cit,hlm. $195-197$

16 Iman Taqiyyudin Abu Bakar Bin Muhammad al-Husaini, Kifayat al-Akhyar, terj.KH.Syarifuddin Anwar, 2007, (Surabaya: Bijna Iman, 2007), hlm. 603

17 Syekh Khotib Asy-Syarbini dan syekh Mughnil Muhtaj, al-mugni almuhtaj fi sarhil minhaj juz 2 (Bairut; ad-darul kutub al-islamiyah). hal 220. 
6. Akad pemberian. Seperti, “Aku berdamai dengan kamu atas rumah ini, sebagian aku ambil dan sebagian lain aku berikan padamu”.

7. Akad pembebasan hutang. Sperti, “Aku berdamai dengan kamu atas hutang mu, sebagian aku ambil dan sebagian lain aku bebaskan darimu.”

8. Akad tebusan. Seperti, “aku berdamai dengan kamu atas rumah ini, dengan ganti kamu bebaskan tawanan itu.”18Karena akad shuluh bisa berlaku dalam beragam akad inilah, selanjutnya ia di gelari sebagai induk segala hukum. ${ }^{19}$

\section{E. Kesimpulan.}

Penyelesaian masalah persengketaan di dalam undang- undang dan hukum agama islam ada yang melalui litigasi dan non ligitasi, kalau melalui ligitasi keliahatan sangat formal dan tidak bebas. Oleh sebab itu orang-orang atau perusahaan dalam menyelesaiakan masalah persengketaan lebih memilih jalur non ligitasi yang meliputi mediasi, negosiasi, arbitrase, dan katalisasi. Pada hukum islam negosiasi bisa masuk kedalam hukum As-Sulhu (perdamaian) yang mana kedua pihak saling bermusyawarah untuk menyelasaikan persengketaan dengan tidak dilakukan di pengadilan. As-sulhu kalau dilihat secara sepintas seperti hanya perdamain biasa, Secara garis besar as-sulhu terbagi menjadi dua yaitu; sulhu al-hathitah yaitu akad al-sulhu dengan cara mengambil sebagian barang yang di persengketakan, dan al-sulhu al-mu'awadhah yaitu akad al-sulhu dengan cara mengganti barang yang di persengketakan, al-sulhu ini hukumnya seperti jual beli. Tetapi menurut Imam Jalaludin As-Suyuti bahwa al-sulhu bisa mengandung beberapa akad muamalah diantaranya jual beli, sewa menyewa, pembebasan hutang. Selanjutnyadidalam kitab tausyeh 'ala ibnu qosim di jelaskan bahwa al-sulhu merupakan induk dari pada beberapa hukum hususnya hukum muamalah artinya bisa mengandung akad-akad muamalah yang lainya.

\footnotetext{
18 Abdurrahman bin Kamaluddin Abu Bakr bin Muhammad bin Sabiquddin, Jalaluddin al-Misri as-Suyuthi, asbah wana dhoir.(Bairrut; ad-darul kutub al-islamiyah). Hal 264-265

19 Abi Abdullah Muhammad bin Qasim As-Syafii, Tausyih ala Ibnu Qasim.( Bairrut;
} 


\section{DAFTAR PUSTAKA}

Abdurrahman bin Kamaluddin Abu Bakr bin Muhammad bin Sabiquddin, Jalaluddin al-Misri as-Suyuthi, asbah wana dhoir.(Bairrut; ad-darul kutub al-islamiyah)

Aravik, Havis. "Penyelesaian Sengketa Konsumen Melalui Jalur Al-Shulhuh Dan Jawatan Al-Hisbah.” Ekonomica Sharia 1, No. 2 (27 Februari 2016): 33-42

Aman. Aly Muhibin, Mengenal Istilah Dan Rumus Fuqaha (Kediri, Madrasah Hidayatul Mubtadiin, 2002)

Amin. Husyn, Ahmad Seratus Tokoh Dalam Sejarah Islam, (Bandung: PT Remaja Rosdakarya, 2006).

Dimyati, Yayat, Hasyim Asy’ari, Dan Musoto Mustoto. “Efektifitas Mediator Dalam Menekan Tingkat Perceraian.” Jurnal Mahkamah: Kajian Ilmu Hukum Dan Hukum Islam 4, No. 1 (16 Juli 2019): 121-36. Https://Doi.Org/10.25217/Jm.V4i1.398.

Fadilla, Fadilla. "Permasalahan Ekonomi Sesungguhnya Dalam Islam.” Islamic Banking : Jurnal Pemikiran Dan Pengembangan Perbankan Syariah 3, No. 1 (31 Agustus 2017): 1-10.

Ghani Abdullahyusrin Abdul, Historiografi Islam Dari Klasik Hingga Modern, (Jakarta: Pt Raja Grapindo Persada, 2004), Cet. Ke-1.

Muhammad. Abi Abdullah bin Qasim As-Syafii, Tausyih ala Ibnu Qasim.( Bairrut; ad-darul kutub al-islamiyah).

Mohd Zafar Ashraf Bin Zulkarnain. "Proses Penyelesaian Sengketa Suami Istri Padalembaga Shulh Mahkamah Rendah Syariahkuala Krai, Kelantan Darul Naim,Malaysiamenurut Perspektif Hukum Islam.” Skripsi, Universitas Islam Negeri Sultan Syarif Kasim Riau, 2015. Http://Repository.Uin-Suska.Ac.Id/7325/.

Hosen. H.M Nadratuzzaman \& AM Hasan Ali, MA Sistem Jaminan Halal pada Bank Syariah.

H. Taufiq, mantan hakim agung Lihat Draft KHES yang disosialisasikan terakhir di PTA Jakarta tanggal 26 Nopember 2007, pasal 34.)

Hasbi Ash Siddiqi, Pengantar Fiqih Muamalat,(Bulan Bintang: Jakarta, 1984), ad-darul kutub al-islamiyah). Hal 284. 
hlm.92

Imam Taqiyuddin Bin Muhammad al- Husaini. Abu Bakar Kifayah al- Akhyar, ( Bandung: PT al- Marif, tt).

Iman Taqiyyudin Bin Muhammad al-Husaini. Abu Bakar Kifayat al-Akhyar, terj.KH.Syarifuddin Anwar, 2007, (Surabaya: Bijna Iman, 2007).

UmamKhotibul, Penyelesaian Sengketa diluar Pengadilan, (Yogyakarta: Penerbit Pustaka Yustisia, 2010).

Rahayu, Fadilah Qotimatun Puji. “Analisis Akta Perdamaian Sengketa Ekonomi Syariah Di Pengadilan Agama Sragen Di Tinjau Dari Al - Shulhu Dan Perma No. 1 Tahun 2016 Tentang Prosedur Mediasi Di Pengadilan.” Jurnal Al-Hakim: Jurnal Ilmiah Mahasiswa, Studi Syariah, Hukum Dan Filantropi 2, No. 2 (28 September 2020): 16-30.

Sabiq. Sayid, Fiqh al- Sunnah,(Dar al- Fiqir, 1987).

Vago. Steven, Law and Society, New Jersey : Printice-Hall, 1988.

Asy-Syarbini Syekh Khotib dan syekh Mughnil Muhtaj, al-mugni almuhtaj fi sarhil minhaj juz 2 (Bairut; ad-darul kutub al-islamiyah).

Yuwanita, Esti. "Hubungan Antara Kualitas Perkawinan Orang Tua Dan Parenting Practices Dengan Regulasi Emosi Pada Remaja Sma Wahid Hasyim 1 Surabaya.” Undergraduate, Universitas Muhammadiyah Surabaya, 2017. Http://Repository.Um-Surabaya.Ac.Id/2412/.

Zuhailywahbah, Al- Fiqih Al - Islami Wa Adillatuhu, (Beirut: Dar Al- Fikr AlMuashir, 2005), Jilid Iv. 
